Kompendium rozpoznań elektrokardiograficznych. Kryteria diagnostyczne przerostu jam serca, cech martwicy, zmian okresu repolaryzacji i rozpoznawania ostrych zespołów wieńcowych. Stanowisko grupy ekspertów Sekcji Elektrokardiologii Nieinwazyjnej i Telemedycyny Polskiego Towarzystwa Kardiologicznego

Electrocardiographic criteria for diagnosis of the heart chamber enlargement, necrosis and repolarisation abnormalities including acute coronary syndromes. Experts' group statement of the Working Group on Noninvasive Electrocardiology and Telemedicine of the Polish Cardiac Society

Rafał Baranowski ${ }^{1}$, Dariusz Wojciechowski ${ }^{2,}{ }^{3}$, Dariusz Kozłowski ${ }^{4}$, Piotr Kukla ${ }^{5}$, Małgorzata Kurpesa ${ }^{6}$, Jacek Lelakowski ${ }^{7}$, Monika Maciejewska ${ }^{8}$, Beata Średniawa ${ }^{9}$, Jerzy Krzysztof Wranicz ${ }^{10}$

${ }^{1}$ Klinika Zaburzeń Rytmu Serca, Instytut Kardiologii, Warszawa

${ }^{2}$ Instytut Biocybernetyki i Inżynierii Biomedycznej, Polska Akademia Nauk, Warszawa

${ }^{3}$ Szpital Wolski im. dr Anny Gostyńskiej, SPZOZ, Warszawa

${ }^{4}$ Klinika Kardiologii i Elektroterapii Serca, Gdański Uniwersytet Medyczny, Gdańsk

${ }^{5}$ Oddział Internistyczno-Kardiologiczny, Szpital Specjalistyczny, Gorlice

${ }^{6}$ Katedra Kardiologii, Uniwersytet Medyczny w Łodzi, Łódź

${ }^{7}$ Klinika Elektrokardiologii, Instytut Kardiologii, Uniwersytet Jagielloński, Collegium Medicum, Krakowski Szpital Specjalistyczny im. Jana Pawła II, Kraków

${ }^{8}$ Klinika Chorób Wewnętrznych, Nadciśnienia Tętniczego i Angiologii, Warszawski Uniwersytet Medyczny, Warszawa

${ }^{9}$ Katedra Kardiologii, Wrodzonych Wad Serca i Elektroterapii, Śląski Uniwersytet Medyczny, Śląskie Centrum Chorób Serca, Zabrze

${ }^{10}$ Klinika Elektrokardiologii, Katedra Kardiologii i Kardiochirurgii, Centrum Kliniczno-Dydaktyczne, Uniwersytet Medyczny w Łodzi, Łódź

Recenzenci/Reviewers:

Prof. dr hab. n. med. Maria Trusz-Gluza

Prof. dr hab. n. med. Jarosław Każmierczak

\section{Kryteria diagnostyczne:}

ZMIANY EKG ZWIĄZANE

Z PRZEROSTEM LUB POWIĘKSZENIEM

JAM SERCA

60. Przerost (nieprawidłowości) lewego przedsionka

- czas trwania załamka P (dotyczy tylko załamków P pochodzenia zatokowego) w odprowadzeniach kończynowych
$>120$ ms (załamek pozazębiany lub dwugarbny i czas między dwoma szczytami $\geq 40 \mathrm{~ms}$ ); i/lub

- w odprowadzeniu V1 załamek P dwufazowy (dodatnio-ujemny) lub ujemny, z czasem trwania fazy ujemnej $\geq 40 \mathrm{~ms}$ i amplitudą $\geq 0,1 \mathrm{mV}(1 \mathrm{~mm})$.

W przypadku występowania w odprowadzeniach II, III, aVF dodatnio-ujemnych załamków P można dodatkowo rozpoznać zaburzenia przewodzenia międzyprzedsionkowego. 
Kryteria diagnostyczne:

\section{Przerost (nieprawidłowości) prawego przedsionka}

- załamki P (dotyczy tylko załamków P pochodzenia zatokowego) o amplitudzie $>0,25 \mathrm{mV}(2,5 \mathrm{~mm}) \mathrm{w}$ co najmniej jednym odprowadzeniu kończynowym; lub

- amplituda dodatniego załamka P lub fazy dodatniej (dwufazowego dodatnio-ujemnego) załamka P w odprowadzeniu V1 lub V2 wynosząca co najmniej $0,15 \mathrm{mV}$ $(1,5 \mathrm{~mm})$.

\section{Przerost (nieprawidłowości) obu przedsionków}

\section{Kryteria diagnostyczne:}

- równoczesne spełnienie kryteriów przerostu (nieprawidłowości) dla lewego i prawego przedsionka.

\section{Przerost lewej komory}

\section{Kryteria diagnostyczne:}

Poniżej przedstawiono kryteria najczęściej stosowane w codziennych opisach elektrokardiograficznych (EKG). U pacjentów bez zaburzeń przewodzenia śródkomorowego spełnienie przynajmniej jednego z poniższych wystarcza do rozpoznania przerostu lewej komory:

- $\mathrm{RwaVL}>1,1 \mathrm{mV}(11 \mathrm{~mm})$;

- RwI + Sw III > 2,5 mV (25 mm);

- Rw V5 lub V6 > 2,6 mV (26 mm);

- $\mathrm{S} w \mathrm{~V} 1+\mathrm{R} w \mathrm{~V} 5$ lub V6 > 3,5 mV (35 mm);

- SwV2 + R w V5 lub V6 > 4,5 mV (45 mm);

- $\mathrm{S} w \mathrm{~V} 3+\mathrm{R} w \mathrm{aVL}>2,8 \mathrm{mV}$ (28 mm) u mężczyzn;

- $\mathrm{S} w \mathrm{~V} 33+\mathrm{R} w \mathrm{aVL}>2 \mathrm{mV}(20 \mathrm{~mm})$ u kobiet.

\section{Przerost lewej komory}

przy obecności bloku przedniej wiązki

Kryteria diagnostyczne (przynajmniej jedno z poniższych):

- S w III (+ maksymalna suma załamków R i S z jednego z odprowadzeń przedsercowych) $>2,8 \mathrm{mV}(28 \mathrm{~mm})$ u kobiet i > $3 \mathrm{mV}$ (30 mm) u mężczyzn;

- S w V1 lub V2 + R w V6 + S w V6 > 2,5 mV (25 mm).

Przerost lewej komory przy obecności bloku prawej odnogi pęczka Hisa (całkowitym)

Kryteria diagnostyczne (przynajmniej jedno z poniższych):

- $\mathrm{RwI}>1,1 \mathrm{mV}(11 \mathrm{~mm})$;

- R w V5 lub V6 > 1,5 mV (15 mm).

Jeżeli w EKG występują cechy bloku przedniej wiązki i bloku prawej odnogi pęczka Hisa, przerost lewej komory należy opisywać, gdy obecne jest przynajmniej jedno z powyższych kryteriów stosowanych w obecności tych zaburzeń przewodzenia śródkomorowego.
Przerost lewej komory przy obecności bloku lewej odnogi pęczka Hisa (całkowitym)

Kryteria diagnostyczne (przynajmniej jedno z poniższych):

- SwV1 + Rw V5 > 4,5 mV (45 mm);

- $\mathrm{SwV} 2+\mathrm{SV} 3>6 \mathrm{mV}(60 \mathrm{~mm})$

- Sw V2 lub V3 + R V5 lub V6 > 4 mV (40 mm)

Kryteria pomocnicze (gdy wystąpią, opisuje się je jako "możliwość przerostu“):

- cechy przerostu lewego przedsionka; czas trwania QRS $>155 \mathrm{~ms}$

Przerost lewej komory przy obecności QRS > $120 \mathrm{~ms}$ oraz niepełnego bloku odnogi pęczka Hisa

lub niespecyficznych zaburzeń przewodzenia śródkomorowego

\section{Kryteria diagnostyczne:}

Stosuje się takie same kryteria jak w EKG bez zaburzeń przewodzenia śródkomorowego. Należy pamiętać, że sam przerost lewej komory może spowodować wydłużenie czasu QRS > 120 ms, co może sprawiać trudności w różnicowaniu z blokiem lewej odnogi pęczka Hisa.

\section{Przerost prawej komory}

Kryteria diagnostyczne (musi być spełnione przynajmniej jedno):

- $\mathrm{R} w \mathrm{wVR} \geq 0,5 \mathrm{mV}(5 \mathrm{~mm})$;

- $\mathrm{R} w \mathrm{~V} 1 \geq 0,7 \mathrm{mV}(7 \mathrm{~mm})$;

- $\mathrm{rSR}^{\prime} \mathrm{w} \mathrm{V} 1-\mathrm{R}^{\prime}>1 \mathrm{mV}(10 \mathrm{~mm})(\mathrm{QRS}<120 \mathrm{~ms})$;

- $\mathrm{SwV}$ V $>1 \mathrm{mV}(10 \mathrm{~mm})$ i $\mathrm{S} w \mathrm{~V} 6>0,3 \mathrm{mV}(3 \mathrm{~mm})$;

- Rw V1 + S w V5 lub V6 > 1,05 mV (10,5 mm).

Kryteria pomocnicze:

- odchylenie osi w prawo (szczególnie gdy oś $>+110$ stopni);

- Rw V1 > Sw V1 lub qR w V1;

_ załamek S w I i załamek Q w III;

- cechy przerostu (nieprawidłowości) prawego przedsionka.

Przerost prawej komory przy obecności bloku prawej odnogi pęczka Hisa

\section{Kryteria diagnostyczne}

— amplituda załamka R w V1 > 1,5 mV (15 mm).

Przerost prawej komory przy obecności bloku lewej odnogi pęczka Hisa

Kryteria diagnostyczne (kryteria dotyczące rozpoznawania poszerzenia prawej komory; muszą być spełnione przynajmniej dwa z poniższych):

— obecność załamka R w końcowej części QRS w aVR;

- woltaż wszystkich odprowadzeń kończynowych $<0,6 \mathrm{mV}$;

$-\mathrm{R} / \mathrm{S} w \mathrm{~V} 5<1$. 


\section{Przerost obu komór \\ Kryteria diagnostyczne:}

Spełnione musi być przynajmniej jedno kryterium dla przerostu prawej i jedno dla przerostu lewej komory. Muszą być spełnione uznane kryteria przerostu lewej komory współistniejące z obecnością głębokich załamków S w V5 lub V6 oraz kryteria przerostu lewej komory współistniejące z osią serca skręconą w prawo i wysokimi dwufazowymi zespołami QRS w kilku odprowadzeniach. U pacjentów z wrodzonymi wadami serca trzeba stwierdzić obecność wysokich dwufazowych zespołów RS w odprowadzeniach przedsercowych V2, V3, V4 (objaw Katz-Wachtela).

\section{ZMIANY ZESPOŁÓW QRS SUGERUJĄCE CECHY MARTWICY}

Prezentacja ścian serca w odprowadzeniach EKG:

— ściana dolna: II, III, aVF;

- ściana przednia: V1-V6;

- ściana boczna: I, aVL, V6;

— ściana dolno-podstawna (dawna tylna): $\mathrm{V} 7-\mathrm{V} 9 \mathrm{i}$ lustrzane zmiany QRST w odprowadzeniach V1-V3;

- prawa komora: V3R-V5R.

\section{Kryteria diagnostyczne:}

\section{Cechy martwicy}

Patologiczny załamek Q (musi występować w przynajmniej dwóch sąsiednich odprowadzeniach z tej samej grupy odprowadzeń, patrz wyżej):

— w odprowadzeniach V2, V3 zespół QS lub załamki Q o jakiejkolwiek amplitudzie i czasie trwania $\geq 20 \mathrm{~ms}$;

— w dwóch dowolnych sąsiadujących odprowadzeniach z grupy - I, aVL, V6; V4-V6; II, III, aVF — zespół QS lub załamki Q o amplitudzie $\geq 0,1 \mathrm{mV}(1 \mathrm{~mm})$ i czasie trwania $\geq 30 \mathrm{~ms}$.

W przypadku martwicy w obszarze ściany dolno-podstawnej występuje nieprawidłowy załamek R w odprowadzeniach V1i/lub V2 - załamek R o czasie trwania $\geq 40 \mathrm{~ms}$ i amplitudzie R/S > 1 z towarzyszącym dodatnim załamkiem T (nie ma zastosowania w zapisach z blokiem prawej odnogi pęczka Hisa lub/i z przerostem prawej komory).

Uwaga: Zapis EKG bez danych klinicznych i/lub bez możliwości porównania z poprzednim EKG nie pozwala ustalić czasu dokonania martwicy. Opisuje się wówczas „cechy martwicy o nieustalonym czasie trwania".

\section{ZMIANY OKRESU REPOLARYZACJI}

\section{Istotne uniesienie odcinka ST}

\section{Kryteria diagnostyczne:}

Uniesienia ST (mierzone w punkcie J) w przynajmniej dwóch odprowadzeniach z tej samej grupy odprowadzeń:

- odprowadzenia $\vee 2, \vee 3-u$ kobiet $\geq 0,15 \mathrm{mV}$ $(1,5 \mathrm{~mm}), \mathrm{u}$ mężczyzn $\mathrm{w}$ wieku $\geq 40$ lat $-\geq 0,2 \mathrm{mV}$
(2 mm), u mężczyzn w wieku $<40$ lat $-\geq 0,25 \mathrm{mV}$ $(2,5 \mathrm{~mm})$;

- odprowadzenia inne niż V2, V3 - u kobiet i mężczyzn $\geq 0,1 \mathrm{mV}(1 \mathrm{~mm})$;

- odprowadzenia V3R i V4R $\geq 0,05 \mathrm{mV}(0,5 \mathrm{~mm})$; u mężczyzn młodszych niż 30 lat $-\geq 0,1 \mathrm{mV}(1 \mathrm{~mm})$;

- odprowadzenia V7-V9 $\geq 0,05 \mathrm{mV}(0,5 \mathrm{~mm})$.

Powyższe kryteria stosuje się do rozpoznawania ostrych zespołów wieńcowych z uniesieniem odcinka ST. Gdy uniesień ST nie można opisać jako rozpoznań: „ostry zespół wieńcowy z uniesieniem ST", „przetrwałe uniesienie ST", „wczesna repolaryzacja”, „ostre zapalenie osierdzia”, to stosuje się rozpoznanie „istotne uniesienie odcinka ST o nieustalonej przyczynie”. Jego zastosowanie jest wynikiem szczegółowej analizy klinicznej, $\mathrm{np}$. stwierdzenia zmian spowodowanych zaburzeniami elektrolitowymi, chorobami centralnego układu nerwowego itp.

\section{Kryteria diagnostyczne:}

\section{Istotne obniżenie odcinka ST}

Obniżenia ST (mierzone w punkcie J) w przynajmniej dwóch odprowadzeniach z tej samej grupy odprowadzeń:

- u kobiet i mężczyzn obniżenie punktu J $\geq 0,05 \mathrm{mV}$ $(0,5 \mathrm{~mm})$.

Ze względu na trudności w tak dokładnym pomiarze odcinka ST w codziennej praktyce zaleca się zwracać uwagę na jakiekolwiek obniżenia ST. Interpretacja obniżeń ST wymaga dokładnej analizy klinicznej, porównania z poprzednim EKG. Kryteria stosuje się do rozpoznania ostrych zespołów wieńcowych bez uniesienia odcinka ST. Gdy nie można zastosować rozpoznań: „ostry zespół wieńcowy bez uniesienia ST", "wtórne zmiany ST", to można po analizie klinicznej opisać zmiany jako „istotne obniżenia odcinka ST o nieustalonej przyczynie".

\section{Zmiany dotyczące załamka T}

\section{Ujemny załamek $T$}

\section{Kryteria diagnostyczne:}

- odwrócenie załamków T (ujemne T) w przynajmniej dwóch odprowadzeniach z tej samej grupy odprowadzeń o amplitudzie $\geq 0,1 \mathrm{mV}$ (1 mm).

Powyższe kryterium jest stosowane w diagnostyce ostrych zespołów wieńcowych bez uniesienia odcinka ST. Jeżeli analiza kliniczna nie wskazuje na to rozpoznanie lub na rozpoznanie ewolucji ostrego zespołu wieńcowego, to opisuje się sam fakt — „ujemne załamki T”.

\section{Wysoki załamek T}

\section{Kryteria diagnostyczne:}

— załamek T dodatni o amplitudzie przekraczającej wartości normy dla danego odprowadzenia $>0,6 \mathrm{mV}$ w odprowadzeniach kończynowych i > 1,0 mV w odprowadzeniach przedsercowych. 


\section{Dwufazowy załamek T, dwugarbny załamek $T$}

\section{Kryteria diagnostyczne:}

- dwufazowy - załamek T o dwóch fazach — dodatnio-ujemny lub ujemno-dodatni w odprowadzeniach innych niż V1;

— dwugarbny — załamek To dwóch szczytach oddalonych od siebie o $<150 \mathrm{~ms}$.

\section{Nieprawidłowa fala $U$}

Kryteria diagnostyczne:

- ujemna (ujemno-dodatnia) fala U; rzadziej chodzi o zwiększoną amplitudę fali $\mathrm{U}(\mathrm{U}>\mathrm{T}$ lub $\mathrm{U}>0,2 \mathrm{mV}-2 \mathrm{~mm})$.

\section{Wtórne zmiany odcinka ST}

\section{Kryteria diagnostyczne:}

- zmiany okresu repolaryzacji — odcinka ST, załamka T i fali U — wynikające z zaburzeń okresu depolaryzacji — zaburzenia przewodzenia śródkomorowego, przerost prawej i/lub lewej komory, preekscytacja, stymulacja komory; opisu wymaga tylko obecność zmian wtórnych do przerostu komór.

\section{Niespecyficzne zmiany odcinka ST}

\section{Kryteria diagnostyczne:}

- w przynajmniej dwóch sąsiednich odprowadzeniach zmiany ST niespełniające kryteriów istotnego obniżenia/uniesienia ST, zmian załamka T, a równocześnie kryteriów normy. Zmiany niespecyficzne rozpoznaje się po wykluczeniu pierwotnych i wtórnych przyczyn zmian okresu repolaryzacji.

\section{Kryteria diagnostyczne:}

\section{Wydłużenie QTc}

— skorygowany odstęp QT (QTc) > 460 ms u kobiet oraz $>450$ ms u mężczyzn;

- przy obecności zaburzeń przewodzenia śródkomorowego (QRS > $120 \mathrm{~ms}$ ) lub stymulacji komory > $500 \mathrm{~ms}$; Uwaga: wysokie ryzyko nagłego zgonu u osób z QTc > 500 ms, szczególnie gdy QTc > 600 ms.

\section{Kryteria diagnostyczne:}

\section{Skrócenie QTc}

- skorygowany odstęp QT (QTc) < 360 ms u kobiet oraz < 350 ms u mężczyzn.

\section{Wczesna repolaryzacja}

Kryteria diagnostyczne (muszą być spełnione wszystkie poniższe kryteria):

- uniesienie punktu J $\geq 0,1 \mathrm{mV}$, w punkcie Jp (J peak) w co najmniej dwóch sąsiadujących odprowadzeniach, wyłączając odprowadzenia V1-V3;

- uniesienie punktu J przebiega jako powolne przejście końcowej fazy zespołu QRS w odcinek ST (QRS slurring) lub jako dodatnie zazębienie (QRS notching). Punkt Jp jest definiowany jako szczyt zazębienia lub jako początek miejsca, w którym QRS przechodzi płynnie w odcinek ST;

- czas trwania zespołu QRS < 120 ms.

Zmiany najczęściej są widoczne w odprowadzeniach znad ściany dolnej (II, III i aVF), bocznej (V5, V6) lub dolno-bocznej.

Wczesna repolaryzacja może przebiegać z uniesieniem odcinka ST lub bez uniesienia odcinka ST.

\section{Kryteria diagnostyczne:}

\section{Fala Osborna - fala J}

- dodatkowe wychylenie zniekształcające końcową część zespołu QRS i początkową część odcinka ST; najczęściej jest obserwowane w odprowadzeniach II, III, aVF, V5, V6.

\section{ZMIANY EKG ZWIĄZANE Z NIEDOKRWIENIEM \\ I MARTWICA (ZAWAŁEM) — OSTRYMI ZESPOŁAMI WIEŃCOWYMI, PRZEBYTYM ZAWALEM SERCA}

Uwaga ogólna dotycząca ostrych zespołów wieńcowych bez uniesienia odcinka ST/istotnego niedokrwienia: ze względu na różną manifestację należy opisać, jakie zmiany ST-T stanowiły podstawę rozpoznania.

90A. Ostry zespót wieńcowy z uniesieniem odcinka ST w obszarze ściany dolnej/ lostry zawat ściany dolnej

\section{Kryteria diagnostyczne:}

- uniesienia (mierzone w punkcie J w przynajmniej dwóch odprowadzeniach): w II, III i aVF — u kobiet i mężczyzn $\geq 0,1 \mathrm{mV}(1 \mathrm{~mm})$.

\section{B. Ostry zespół wieńcowy bez uniesienia odcinka ST w obszarze ściany dolnej/ /istotne niedokrwienie}

\section{Kryteria diagnostyczne:}

Obniżenia ST mierzone w punkcie J w przynajmniej dwóch odprowadzeniach:

- w II, III i aVF obniżenie ST $\geq 0,05 \mathrm{mV}(0,5 \mathrm{~mm})$; i/lub

- odwrócenie załamków T (ujemne T) w II, III i aVF o amplitudzie $\geq 0,1 \mathrm{mV}(1 \mathrm{~mm})$; i/lub

- normalizacja wcześniej ujemnych załamków T w II, III i aVF w trakcie objawów klinicznych (konieczne porównanie z wcześniejszym EKG);

— powyższym może towarzyszyć wydłużenie QTc.

90C. Cechy martwicy ściany dolnej/ /zawał o nieokreślonym czasie trwania

\section{Kryteria diagnostyczne:}

- w przynajmniej dwóch odprowadzeniach z grupy II, III, aVF — zespół QS lub załamki Q o amplitudzie $\geq 0,1 \mathrm{mV}$ $(1 \mathrm{~mm})$ i czasie trwania $\geq 30 \mathrm{~ms}$, którym może towarzyszyć różny obraz zmian ST-T. 
91A. Ostry zespół wieńcowy z uniesieniem odcinka ST w obszarze ściany przedniej/

\section{Kryteria diagnostyczne:} /ostry zawał ściany przedniej

Uniesienia ST mierzone w punkcie J w przynajmniej dwóch odprowadzeniach:

— V2, V3 - u kobiet $\geq 0,15 \mathrm{mV}(1,5 \mathrm{~mm})$, u mężczyzn w wieku $\geq 40$ lat $-\geq 0,2 \mathrm{mV}(2 \mathrm{~mm})$, u mężczyzn w wieku $<40$ lat $-\geq 0,25 \mathrm{mV}(2,5 \mathrm{~mm})$;

- V1, V4-V6 - u kobiet i mężczyzn $\geq 0,1 \mathrm{mV}(1 \mathrm{~mm})$.

91B. Ostry zespół wieńcowy bez uniesienia odcinka ST w obszarze ściany przedniej/ /istotne niedokrwienie

\section{Kryteria diagnostyczne:}

Obniżenia ST mierzone w punkcie J:

- odprowadzenia I, aVL, V1-V6 - u kobiet i mężczyzn obniżenie punktu $\mathrm{J} \geq 0,05 \mathrm{mV}(0,5 \mathrm{~mm})$; i/lub

- odwrócenie załamków T (ujemne T) o amplitudzie $\geq 0,1 \mathrm{mV}(1 \mathrm{~mm}) \mathrm{w} \mathrm{I}, \mathrm{aVL}, \mathrm{V} 2-\mathrm{V} 6$; i/lub

- normalizacja wcześniej ujemnych załamków T w trakcie objawów klinicznych w I, aVL, V1-V6 (konieczne porówanie z wcześniejszym EKG);

— powyższym może towarzyszyć wydłużenie QTc.

91C. Cechy martwicy ściany przedniej/ /zawał serca o nieokreślonym czasie trwania

\section{Kryteria diagnostyczne:}

Występowanie patologicznego załamka Q w przynajmniej dwóch sąsiednich odprowadzeniach z grupy V2-V6. Kryteria patologicznego załamka Q obejmują:

— w odprowadzeniach V2, V3 — załamki Q o jakiejkolwiek głębokości i czasie trwania $\geq 20$ ms lub zespół QS;

- w odprowadzeniach V4-V6 — załamki Q o amplitudzie $\geq 0,1 \mathrm{mV}(1 \mathrm{~mm})$ i czasie trwania $\geq 30 \mathrm{~ms}$ lub zespół QS; mogą im towarzyszyć rożne formy zmian ST i/lub ujemne załamki T.

Inne obrazy EKG wskazujące na ostry zespół wieńcowy z uniesieniem odcinka ST w obszarze ściany przedniej

(wskazujące na konieczność pilnego wykonania koronarografii bez typowego obrazu uniesień ST w 12-odprowadzeniowym EKG)

91D. Ostry zespół wieńcowy w obszarze ściany przedniej zwiazany z zamknięciem/ /zwężeniem pnia lewej tętnicy wieńcowej

(lub choroba wielonaczyniowa)

Kryteria diagnostyczne:

— istotne obniżenia odcinka ST $>1 \mathrm{~mm}$ w przynajmniej 8 odprowadzeniach EKG, istotne uniesienia ST w aVR i/lub w V1
91E. Ostry zespół wieńcowy w obszarze ściany przedniej związany z podejrzeniem zamknięcia/ /zwężenia części proksymalnej gałęzi przedniej zstępującej (zespół Wellensa)

\section{Kryteria diagnostyczne:}

- ujemne załamki T (z lub bez istotnych uniesień/obniżeń ST) w odprowadzeniach V1-V4 (wg niektórych stanowisk w V1-V6), często z wydłużeniem QTc.

\section{F. Początkowe stadium ostrego niedokrwienia}

\section{Kryteria diagnostyczne:}

— w co najmniej dwóch sąsiednich odprowadzeniach wysokie, szpiczaste, symetryczne załamki $\mathrm{T}>1,0 \mathrm{mV}$ $(10 \mathrm{~mm})$ w odprowadzeniach przedsercowych; $>0,6 \mathrm{mV}$ (6 mm) w odprowadzeniach kończynowych.

\section{A. Ostry zespół wieńcowy z uniesieniem odcinka ST w obszarze ściany bocznej/ lostry zawał ściany bocznej}

\section{Kryteria diagnostyczne:}

- uniesienia odcinka ST (mierzone w punkcie J w przynajmniej dwóch odprowadzeniach): w I, aVL, czasem również w V6 - u kobiet i mężczyzn $\geq 0,1 \mathrm{mV}$ (1 mm).

\section{B. Ostry zespół wieńcowy bez uniesienia odcinka ST w obszarze ściany bocznej/ /istotne niedokrwienie}

\section{Kryteria diagnostyczne:}

Obniżenia odcinka ST mierzone w punkcie J w przynajmniej dwóch odprowadzeniach

— w I, aVL (czasem również w V6) - u kobiet i mężczyzn $\geq 0,05 \mathrm{mV}(1 \mathrm{~mm})$; i/lub

— odwrócenie załamków T (ujemne T) w I, aVL (czasem w V6) o amplitudzie $\geq 0,1 \mathrm{mV}$ (1 mm), gdy załamek R/S $>1$ (może temu towarzyszyć wydłużenie QTc); i/lub

- normalizacja wcześniej ujemnych załamków T w I, aVL (czasem w V6) w trakcie objawów klinicznych (konieczne porówanie z wcześniejszym EKG).

\section{C. Cechy martwicy ściany bocznej/zawał serca o nieokreślonym czasie trwania}

\section{Kryteria diagnostyczne:}

- w co najmniej dwóch odprowadzeniach z grupy I, aVL, V6 załamki Q o amplitudzie $\geq 0,1 \mathrm{mV}(1 \mathrm{~mm})$ i czasie trwania $\geq 30$ ms lub zespół QS.

93A. Ostry zespół wieńcowy z uniesieniem odcinka ST w obszarze ściany dolno-podstawnej (dawnej tylnej)/ostry zawał ściany dolno-podstawnej Kryteria diagnostyczne:

— obniżenia ST > $1 \mathrm{~mm}$ w V1, V2, V3.

\section{Kryteria dodatkowe:}

— w odprowadzeniach V1 i V2 załamek R o czasie trwania $\geq 40 \mathrm{~ms}$ i amplitudzie $\mathrm{R} / \mathrm{S} \geq 1$; i/lub 
— istotne uniesienia ST w przynajmniej jednym z odprowadzeń: I, II, III, aVF, aVL, V6.

Jeżeli nie są spełnione kryteria dodatkowe, to konieczna jest rejestracja EKG z odprowadzeń V7-V9. Uniesienia ST (mierzone w punkcie J) w tych odprowadzeniach $\geq 0,05 \mathrm{mV}$ $(0,5 \mathrm{~mm})$ potwierdzają ostry zespół wieńcowy z uniesieniem odcinka ST w obszarze ściany dolno-podstawnej.

93B. Cechy martwicy ściany dolno-podstawnej (dawnej ściany tylnej)/zawał o nieokreślonym czasie trwania

\section{Kryteria diagnostyczne:}

- w odprowadzeniach V1 i/lub V2 załamek R o czasie trwania $\geq 40$ ms i amplitudzie R/S $\geq 1$ ( $w$ V1, V2 zmienny obraz załamka T, najczęściej załamek T jest dodatni); zwykle współistnieją cechy martwicy w innym obszarze serca; możliwe cechy martwicy w odprowadzeniach V7-V9.

\section{Kryteria diagnostyczne:}

\section{Zawał prawej komory}

- uniesienie odcinka ST w punkcie J w odprowadzeniach V3R i V4R $\geq 0,05 \mathrm{mV}(0,5 \mathrm{~mm})$ - u kobiet i mężczyzn $\geq 30$ rż., u mężczyzn w wieku < 30 lat - uniesienie ST $\geq 0,1 \mathrm{mV}(1 \mathrm{~mm})$;

Zawał prawej komory należy podejrzewać, gdy ostremu zawałowi ściany dolnej towarzyszy uniesienie odcinka ST w odprowadzeniu V1. W rzadkich przypadkach zawał prawej komory spowodowany zamknięciem tętnicy prawokomorowej (najczęściej w czasie interwencji wieńcowej) może się manifestować istotnymi uniesieniami ST w odprowadzeniach V1-V5.

95. Podejrzenie ostrego zespołu wieńcowego/ /martwicy w zaburzeniach przewodzenia śródkomorowego, preekscytacji, przerostach komór

95A. Podejrzenie ostrego zespołu wieńcowego w ewolucjach przewiedzionych z blokiem lewej odnogi pęczka Hisa/ostry zawał serca

\section{Kryteria diagnostyczne:}

Musi występować jedno z poniższych przynajmniej w jednym odprowadzeniu:

- uniesienie odcinka ST $\geq 0,1 \mathrm{mV}(1 \mathrm{~mm})$ w odprowadzeniach z dodatnimi zespołami QRS;

- obniżenie odcinka ST $\geq 0,1 \mathrm{mV}(1 \mathrm{~mm})$ w odprowadzeniach $\mathrm{V} 1-\mathrm{V} 3$;

- uniesienie odcinka ST $\geq 0,5 \mathrm{mV}$ (5 mm) w odprowadzeniach z ujemnymi zespołami QRS.

\section{B. Podejrzenie martwicy w ewolucjach przewiedzionych z blokiem lewej odnogi pęczka Hisa}

\section{Kryteria diagnostyczne:}

- obecność zespołów QR w I, II, III, aVF, V5 i V6 (Q Z 30 ms, w przynajmniej jednym odprowadzeniu);
- objaw Cabrery — zazębienia o czasie trwania $\geq 40 \mathrm{~ms}$ części wstępującej załamka S w V3-V5 (wystarczy w jednym odprowadzeniu);

- objaw Chapmana - zazębienia części wstępującej załamka R w I, aVL, V5 i V6 (wystarczy w jednym odprowadzeniu);

- regresja załamków $\mathrm{R}$ (przynamniej $3 \mathrm{~mm}$ ) w odprowadzeniach V1-V4.

95C. Podejrzenie ostrego zespołu wieńcowego/ /martwicy w ewolucjach przewodzonych

$$
\text { z preekscytacja }
$$

\section{Kryteria diagnostyczne:}

Nie ma jednoznacznych i pewnych kryteriów diagnostycznych rozpoznania ostrego zespołu wieńcowego/ostrego zawału w ewolucjach przewiedzionych z preekscytacją. Ocenę odcinka ST zaburza również różny stopień preekscytacji. W przypadku obecności pełnych cech preekscytacji stwierdzenie braku przeciwstawności ST-T w stosunku do przeważającego wychylenia QRS lub uniesień ST o co najmniej $1 \mathrm{~mm}$ w odprowadzeniach z przeważającym załamkiem R opisuje się jako podejrzenie ostrego zespołu wieńcowego, które wymaga interpretacji na podstawie danych klinicznych.

Nie ocenia się martwicy w ewolucjach przewodzonych z preekscytacją.

95D. Podejrzenie ostrego zespołu wieńcowego/ /martwicy w ewolucjach przewodzonych z nieokreślonymi zaburzeniami przewodzenia śródkomorowego, gdy QRS > $120 \mathrm{~ms}$

\section{Kryteria diagnostyczne:}

Nie ma jednoznacznych i pewnych kryteriów diagnostycznych rozpoznania ostrego zespołu wieńcowego/ostrego zawału w ewolucjach przewiedzionych z niespecyficznymi zaburzeniami przewodzenia śródkomorowego (QRS > 120 ms). Stwierdzenie braku przeciwstawności ST-T w stosunku do przeważającego wychylenia QRS lub uniesień odcinka ST o co najmniej $1 \mathrm{~mm}$ w odprowadzeniach z przeważającym załamkiem $\mathrm{R}$ opisuje się jako podejrzenie ostrego zespołu wieńcowego, które wymaga interpretacji na podstawie danych klinicznych.

Nie ma jednoznacznych i pewnych kryteriów diagnostycznych rozpoznania martwicy w ewolucjach z nieokreślonymi zaburzeniami przewodzenia śródkomorowego, jednak występowanie QRS (przynajmniej w jednym odprowadzeniu) w konfiguracji QR (Q $\geq 30 \mathrm{~ms}$ ) nakazuje opisanie ich jako „podejrzenie martwicy".

95E. Podejrzenie ostrego zespołu wieńcowego/ /martwicy w przypadku występowania kryteriów przerostu prawej i/lub lewej komory

\section{Kryteria diagnostyczne:}

Zmiany odcinka ST zgodne z przeważającym wychyleniem zespołów QRS (uniesienia ST przy dominującym R, 
obniżenia ST przy dominującym S) nakazują pilną weryfikację kliniczną w kierunku ostrego zespołu wieńcowego.

Obecność skośnych do dołu obniżeń ST i/lub ujemnych załamków T w zespołach z dominującym załamkiem R nie jest kryterium diagnostycznym ostrego zespołu wieńcowego bez uniesienia odcinka ST.

Stwierdzenie patologicznych załamków Q (wg standardowych kryteriów) nasuwa podejrzenie martwicy/zawału serca o nieokreślonym czasie trwania.

\section{A. Podejrzenie ostrego zespołu wieńcowego/} /ostrego zawału serca w stymulacji

\section{Kryteria diagnostyczne:}

Diagnostyka w zespołach własnych (jeżeli występują

i QRS $<120 \mathrm{~ms}$ ):

- obecność istotnych uniesień odcinka ST zawsze traktuje się jako cechę ostrego zespołu wieńcowego (niezależnie od rodzaju wszczepionego rozrusznika);

- gdy jest to rozrusznik przedsionkowy AAI, obniżenia ST i ujemne załamki T należy traktować jako podejrzenie ostrego zespołu wieńcowego;

- obniżenia odcinka ST/ujemne załamki T najczęściej są związane ze zjawiskiem pamięci elektrycznej (nie dotyczy stymulatorów AAI).

Diagnostyka w zespołach wystymulowanych — stymulacja w komorze (musi być spełnione jedno z poniższych kryteriów, przynajmniej w jednym odprowadzeniu):

- obniżenie odcinka ST $\geq 1 \mathrm{~mm}$ w odprowadzeniach z ujemnym wychyleniem zespołu QRS;

- uniesienie odcinka ST $\geq 1 \mathrm{~mm}$ w odprowadzeniach z dodatnim wychyleniem zespołu QRS;

- uniesienie odcinka ST > $5 \mathrm{~mm}$ w odprowadzeniach z ujemnym wychyleniem zespołu QRS.

\section{B. Podejrzenie martwicy w stymulacji Kryteria diagnostyczne:}

Ocenę załamków Q w ewolucjach rytmu własnego opiera się na kryteriach standardowych. Gdy jest obecna stymulacja AAI, stosuje się kryteria standardowe. Gdy są tylko ewolucje QRS stymulacji w komorze, stosuje się poniższe kryteria:

- po impulsie stymulacji zespół QRS w konfiguracji QR (jakikolwiek załamek Q) w odprowadzeniach II, III, aVF, V5 i V6 (wystarczy jedno odprowadzenie);

- objaw Cabrery - zazębienia części wstępującej załamka S w odprowadzeniach V3-V5 (wystarczy jedno odprowadzenie) o czasie trwania $\geq 40 \mathrm{~ms}$;

- objaw Chapmana — zazębienia części początkowej zespołu QRS w odprowadzeniach I, aVL, V5 i V6 (wystarczy jedno odprowadzenie).

W przypadku stymulacji resynchronizujacej obecność powższych cech martwicy ma mniejszą wartość diagnostyczną.

\section{KODY ROZPOZNAŃ EKG, KTÓRYCH STOSOWANIE WYMAGA ZNAJOMOŚCI DANYCH KLINICZNYCH I/LUB MOŻLIWOŚCI PORÓWNANIA Z POPRZEDNIMI EKG}

\section{Ewolucja zawału serca \\ Kryteria diagnostyczne:}

Są stosowane tylko do opisów EKG wykonywanych we wczesnym okresie ostrego zespołu wieńcowego z uniesieniem odcinka ST. Rozpoznanie ewolucji zawału serca jest możliwe na podstawie analizy kolejnych zapisów EKG u pacjenta z potwierdzonym, określonym co do czasu rozpoczęcia ostrego zespołu wieńcowego z uniesieniem ST, w których obserwuje się charakterystyczną dynamikę zmian ST (zmiany amplitudy uniesienia/obniżenia ST, amplitudy i polarności załamków T).

\section{Podejrzenie dorzutu zawału serca}

\section{Kryteria diagnostyczne:}

Rozpoznanie dorzutu zawału serca jest możliwe na podstawie analizy kolejnych zapisów EKG u pacjenta z potwierdzonym ostrym zespołem wieńcowym, u których obserwuje się w przynajmniej dwóch odprowadzeniach (w których wcześniej stwierdzono zmiany ST) ponowne wystąpienie uniesienia $\mathrm{ST} \geq 0,1 \mathrm{mV}$ w stosunku do obrazu wcześniejszego lub pojawienie się nowych załamków Q. Powyższe zmiany w EKG mają związek z wystąpieniem przez minimum 20 minut objawów klinicznych.

\section{Przebyty zawał serca}

\section{Kryteria diagnostyczne:}

- cechy martwicy w EKG; dane kliniczne (lub poprzednie EKG) potwierdzające przebyty zawał serca i brak klinicznego podejrzenia ostrego zespołu wieńcowego.

\section{Przetrwałe istotne zmiany okresu} repolaryzacji - przetrwałe uniesienie odcinka ST, przetrwałe obniżenie odcinka ST, przetrwałe ujemne załamki $T$

\section{Kryteria diagnostyczne:}

- zmiany okresu repolaryzacji - istotne uniesienia odcinka ST, istotne obniżenia odcnka ST, ujemne załamki T (mogą występować osobno lub po dwa lub trzy rodzaje zmian równocześnie) współistniejące lub nie z cechami martwicy;

- dane kliniczne lub poprzednie EKG wskazujące na przebyty zawał serca i/lub na stałość nieprawidłowych zmian okresu repolaryzacji bez cech klinicznych ostrego zespołu wieńcowego;

- brak cech dorzutu zawału serca — patrz kod „podejrzenie dorzutu zawału". 
Uwaga techniczna: Podane w milimetrach wartości amplitud i zmiany położenia odcinków dotyczą najczęściej stosowanej cechy: $1 \mathrm{mV}=10 \mathrm{~mm}$.

Konflikt interesów: nie zgłoszono

\section{Piśmiennictwo}

(najważniejsze pozycje piśmiennictwa wykorzystane w przygotowaniu niniejszego dokumentu)

Baranowski R, Małek L, Prokopowicz D, Spiewak M, Miśko J. Electrocardiographic diagnosis of the left ventricular hypertrophy in patients with left bundle branch block: is it necessary to verify old criteria? Cardiol J, 2012; 19: 591-595.

Bozzi G, Figina A. Left anterior hemiblock and electrocardiographic diagnosis of left ventricular hypertrophy. Adv Cardiol, 1976; 16: 495-500.

Dąbrowska B, Dąbrowski A. Podręcznik elektrokardiografii. PZWL, Warszawa 2005.

Hanckock EW, Deal BJ, Mirvus DM et al. AHA/ACC HRS Recommendations for the Standarization and Interpretation of the Electrocardiogram: Part V: Electrocardiogram Changes Associated With Cardiac Chamber Hypertrophy A Scientific Statement From the American Heart Association Electrocardiography and Arrhythmias Committee, Council on Clinical Cardiology; the American College of Cardiology Foundation; and the Heart Rhythm Society Endorsed by International Society for Computerized Electrocardiology. J Am Coll Cardiol, 2009; 53: 992-1002. doi: 10.1016/j. jacc.2008.12.015.

Rautaharju PM, Surawicz B, Gettes LS et al.; American Heart Association Electrocardiography and Arrhythmias Committee, Council on Clinical Cardiology; American College of Cardiology Foundation; Heart Rhythm Society. AHA/ACCF/HRS recommendations for the standardization and interpretation of the electrocardiogram: part IV: the ST segment, $\mathrm{T}$ and $\mathrm{U}$ waves, and the QT interval: a scientific statement from the American Heart
Association Electrocardiography and Arrhythmias Committee, Council on Clinical Cardiology; the American College of Cardiology Foundation; and the Heart Rhythm Society. Endorsed by the International Society for Computerized Electrocardiology. J Am Coll Cardiol, 2009; 53: 982-991. doi: 10.1016/j. jacc.2008.12.014.

Surawicz B, Knilans TK. Chou's electrocardiography in clinical practice. W.B. Saunders Company, Philadelphia 2001.

Thygesen K, Alpert JS, Jaffe AS et al. Third definition of myocardial infarction. Expert consensus document. Eur Heart J, 2012; 33: 2551-2267. doi: 10.1093/eurheartj/ehs184.

Vandenberg BF, Romhilt DW. Electrocardiographic diagnosis of left ventricular hypertrophy in the presence of bundle branch block. Am Heart J, 1991; 122: 8180-8822.

Wagner GS, Macfarlane P, Wellens H et al.; American Heart Association Electrocardiography and Arrhythmias Committee, Council on Clinical Cardiology; American College of Cardiology Foundation; Heart Rhythm Society. AHA/ACCF/HRS recommendations for the standardization and interpretation of the electrocardiogram: part VI: acute ischemia/infarction: a scientific statement from the American Heart Association Electrocardiography and Arrhythmias Committee, Council on Clinical Cardiology; the American College of Cardiology Foundation; and the Heart Rhythm Society. Endorsed by the International Society for Computerized Electrocardiology. J Am Coll Cardiol, 2009; 53: 1003-1011. doi: 10.1016/j.jacc.2008.12.016.

Wagner GS. Elektrokardiografia praktyczna. Wyd. Medyczne Urban \& Partner, Wrocław 1999.

Wellens HJ, Conover M. In: Fuglewicz A, Ponikowski P eds. EKG w stanach nagłych. Wyd. I (pol.). Elsevier Urban \& Partner, Wrocław 2006.

Zalecenia dotyczące stosowania rozpoznań elektrokardiograficznych. Dokument opracowany przez Grupę Roboczą powołaną przez Zarząd Sekcji Elektrokardiologii Nieinwazyjnej i Telemedycyny Polskiego Towarzystwa Kardiologicznego. Komitet Redakcyjny: Baranowski R, Wojciechowski D, Maciejewska M. Kardiol Pol, 2010; 68 (supl. IV): S333-S390.

Cite this article as: Baranowski R, Wojciechowski D, Kozłowski D et al. Kompendium rozpoznań elektrokardiograficznych. Kryteria diagnostyczne przerostu jam serca, cech martwicy, zmian okresu repolaryzacji i rozpoznawania ostrych zespołów wieńcowych. Stanowisko grupy ekspertów Sekcji Elektrokardiologii Nieinwazyjnej i Telemedycyny Polskiego Towarzystwa Kardiologicznego. Kardiol Pol, 2016; 74: 812-819. doi: 10.5603/KP.2016.0119. 